\title{
French cash pull-out puts Cluster in doubt
}

Munich. New doubts have been raised about whether the Cluster satellite mission will fly again, despite support for the plan from the European Space Agency (ESA). Last week, France unexpectedly told ESA's decision-making science programme committee (SPC) that it is not prepared to pay for the scientific instruments, which were destroyed when Cluster's Ariane-5 launcher exploded during its first launch in June, to be rebuilt.

France is one of the biggest participants in the four-satellite Cluster programme. If it does not reverse its decision, the relaunch, known as Cluster II, will almost certainly have to be abandoned. Under ESA's standard procedures, Cluster's four satellites must be paid for by ESA. But the scientific instruments that the satellites carry as payload must be paid for by participating member states.

Last month, ESA's space science advisory committee voted unanimously to support Cluster II, backing a ECU210-million (US\$168-million) plan to build the four new satellites and pay for their launch (see Nature 384, 99; 1996).

Even the day before last week's SPC meeting, participating member states including the United States, the United Kingdom, France, Germany and Sweden were said to be optimistic that money would somehow be made available for instruments. Although they are still very expensive, the cost of replacing the instruments is less than half the original cost, which included all the development expenses. The cost of rebuilding the instruments, according to a 'minimum payload plan' designed by the Cluster programme committee, would be around $£ 7$ million (US\$4.16 million) for the United Kingdom, for example, less than DM10 million (US\$6.53 million) for Germany, and around FFr50 million

\section{IMAGE UNAVAILABLE FOR COPYRIGHT REASONS}

Cluster's last stand? French priorities may lie with Ariane-5 rather than Cluster (above).

(US\$9.57 million) for France.

But only a few hours before the SPC meeting began, the French delegation received instructions from François d'Aubert, France's research minister, to inform ESA that France would not contribute anything to the new payload plan. No explanation for the unexpected announcement appears to have been given by either the French research ministry or CNES, the French space agency. ESA officials declined to comment on Monday, but a statement from d'Aubert's office indicated that he might be prepared to negotiate with ESA over payment for instruments "once he has more information".

One factor in France's sudden reluctance to finance Cluster II could be the future of 政 Ariane-5. This is part of ESA's optional \& launcher programme, which is where France in has its greatest interest. The Ariane-5 क programme found itself short of hundreds of millions of ECU as a result of the failure of its maiden voyage (see Nature 383, 368; 1996). France may prefer any available funding to be used in support of the launcher, rather than in saving a basic science mission.

Despite the uncertainty surrounding the financing of the payload, the SPC voted to continue planning for Cluster II. It will put the building of the satellites out to tender in the next few weeks. But a final decision on whether Cluster II will be built will have to wait for SPC's next meeting in February.

Meanwhile, both ESA's space science directorate and Cluster scientists are hoping that d'Aubert will be persuaded to change his mind. Paul Murdin, SPC delegate from Britain's Particle Physics and Astronomy Research Council, admits that the French announcement is "obviously very difficult", but says he remains optimistic that Cluster II will go ahead.

Alison Abbott

\section{Policy differences 'threaten Israel's biotech potential'}

Jerusalem. Disagreement within the Israeli government about the economic potential of the country's fledgling biotechnology industry could prevent the sector from reaching its full potential. That was the message from speakers last week at a conference at the Weizmann Institute of Science in Rehovot sponsored by the National Committee for Biotechnology.

Haim Aviv, chairman of the committee and a former professor of biology at the Weizmann Institute, said that the industry could improve on its 1995 sales of US\$249.3 million by an order of magnitude over the next ten years. But it needs investment of between $\mathbf{\$ 1 0 0}$ million and $\mathbf{\$ 2 0 0}$ million to do so. Such investment is unlikely to come from private-venture capitalists, said Aviv, as the industry is still in its infancy and there are long lead times between basic research and marketable products.

The Ministry of Science seems to share the confidence that Israel has the potential to become a major player in biotechnology. It has budgeted almost $\$ 6$ million this year for development projects intended to bridge the gap between basic research and market- able products. But the Department of Commerce is holding back from making any major commitment, saying that it is unconvinced that Israel has a competitive advantage in biotechnology.

Leah Boehm, chief scientist at the science ministry, pointed out that more than one third of Israel's scientists work in the life sciences. Aviv confirmed this potential by adding that one per cent of all publications worldwide in the life sciences are by Israeli authors - 100 times more than would be expected from the number of scientists in the country.

The problem, Aviv said, is that Israel has not been good at translating its basic research into products. But he believes that is changing. He pointed out that Copaxone, a multiple sclerosis drug developed by Israel's largest pharmaceutical company, Teva, has won approval this year from the US Food and Drug Administration.

But the commerce department, which has a much larger budget than the science ministry for supporting research and development in new industries, is cooler about the economic potential of biotech- nology. This is despite the fact that it approved this year a $\$ 49.2$-million, five-year investment fund for the development of drugs and diagnostic tools, and a similar \$7.5-million grant for the development of seaweed products.

Yishai Laks, adviser to the commerce department's director-general, says: "We don't believe that the biotechnology industry is an appropriate place to make massive investments. It has only long-term potential and we are not convinced that Israel has a competitive advantage. If the private sector has avoided investing in the field, we shouldn't [invest] either."

According to Laks, the department believes that Israel will benefit more from government investment in high-tech electronics. But Aviv argues that it is precisely because biotechnology is still too risky to attract private investors that the government needs to make a major commitment. One of the reasons that Israel has been so successful in electronics, he claims, is that the defence ministry invested heavily in the field and created the infrastructure that biotechnology lacks. 